\title{
THE FUNCTION OF THE RUMP IN RELATION TO SITTING AND THE KEANE RECIPROCATING WHEELCHAIR SEAT
}

\author{
By F. X. Keane, M. B., B.Ch., B.A.O. \\ Spinal Unit, National Medical Rehabilitation Centre, Dun Laoghaire, Co. Dublin, Ireland
}

Abstract. There is no appliance which will prevent decubiti in the immobile patient. Rump function in relation to man is discussed. Body weight is carried on the skeleton and transmitted to a natural surface, i.e. the ground via weight bearing superficial bony prominences. These protect vital structures: muscle, urethra, nerves, arteries from the effects of pressure. Convential seat appliances are unscientific, and seek to relieve pressure on the skin in the area of the ischia by transferring pressure to the soft tissues. Consequently, the physiological condition is reversed, the skeleton and body weight is supported on vital tissues. This leads to serious and deep necrosis which starts within the warm ischaemic muscle survival time which is much shorter than survival time for skin.

It would appear that there is no safe method of preventing decubiti except the normal physiological means: mobilisation of the patient.

The Keane Reciprocating Wheelchair Seat consists substantially of an outer support means of conventional toilet seat shape and an inner mechanically operated central seat which lifts the patient in a physiological way on the ischia once every $9 \mathrm{~min}$, thus there is adequate transfer of weight from one large area of the buttocks to another. Therefore prolonged ischaemia is avoided. It has been observed that under restoration of adequate mobility ischial decubiti will heal. Intermittent pressure produced by body weight is normal for tissue and repair by cicatrisation. Consequently, bedrest with interruption of occupation is not necessary in the treatment of ischial sores.

Key words: Decubiti; Ischial sores; Paraplegia; Nursing care.

\section{Introduction}

THE sitting posture is essential for practical rehabilitation. To my knowledge no seat exists which will prevent decubiti in the immobile patient. By adolescence, the rump of paraplegic children is so mutilated, that continuity of occupation is impossible. Many patients in fact sit on chronic ulcers.

Kosiak (1958) and Houle (1969) measured pressures on the skin under the buttocks, on a variety of seat devices. Only the Alternating Slatted Seat reduced the pressure below capillary blood pressure. Because ulcers are visible in the skin, and arise near the ischia, and because pressure has been stressed so much as the aetiological factor, relief or reduction of pressure on the skin over the ischia has remained the purpose of all seat devices. All these appliances ignore the work of Groath (I942), Guttmann (I953), Husain (I953), Kosiak (I959) and Haimovici (1976) who proved that muscle is injured by a period of ischaemia well in advance of skin necrosis. Therefore, all gangrenous sores arise in the deep tissues; ulceration or gangrene of the skin occurs last. Using conventional seats, it is not pressure measurement on the skin, but the compression tension and distortion in the deep tissues that is important. As a result, non physiological seats are used, which speed the production and size of sores. An example is the widely used wheelchair cushion. It might also be added that appliances which reduce 
pressure on the skin over the tuberosities remove the natural stimulus to produce thickened protective skin (Gray, I969).

\section{Rump Function in Relation to Sitting}

Man is a terrestrial animal. Body form is preserved by a skeleton on which the soft tissues and viscera are suspended. Weight therefore is transferred to the ground by bony prominences. During the activities of daily living the tissues are not injured by the pressures exerted by body weight against a natural hard surface. Consequently, pressure per se is not an aetiological factor in the production of decubiti. The pressures encountered are normal. It is immobility that is the abnormal factor which gives rise to prolonged ischaemia. The skeleton protects vital structures such as muscle, nerves and arteries, etc. by weight bearing bony prominences, covered only by skin and superficial fascia.

The ischial tuberosities emerge from under the gluteus maximus as the hips flex to sit. Muscle is thereby protected from crushing pressure. When man sits on a hard flat surface, the bilateral arrangement of the ischia provide stabilisation of the pelvis and body balance, with minimal work. The ischial bursa of gluteus maximus protects the muscle from the tuberosity, and not the ischium from pressure, when man sits on a hard surface. Indeed, the bursa is often absent (Gray, I969).

In order to observe the buttocks seated on a hard flat surface, a patient was photographed through a horizontal sheet of glass (see Fig. I). Only a small area of skin directly over the bone is rendered ischaemic. Kosiak (1958) recorded a

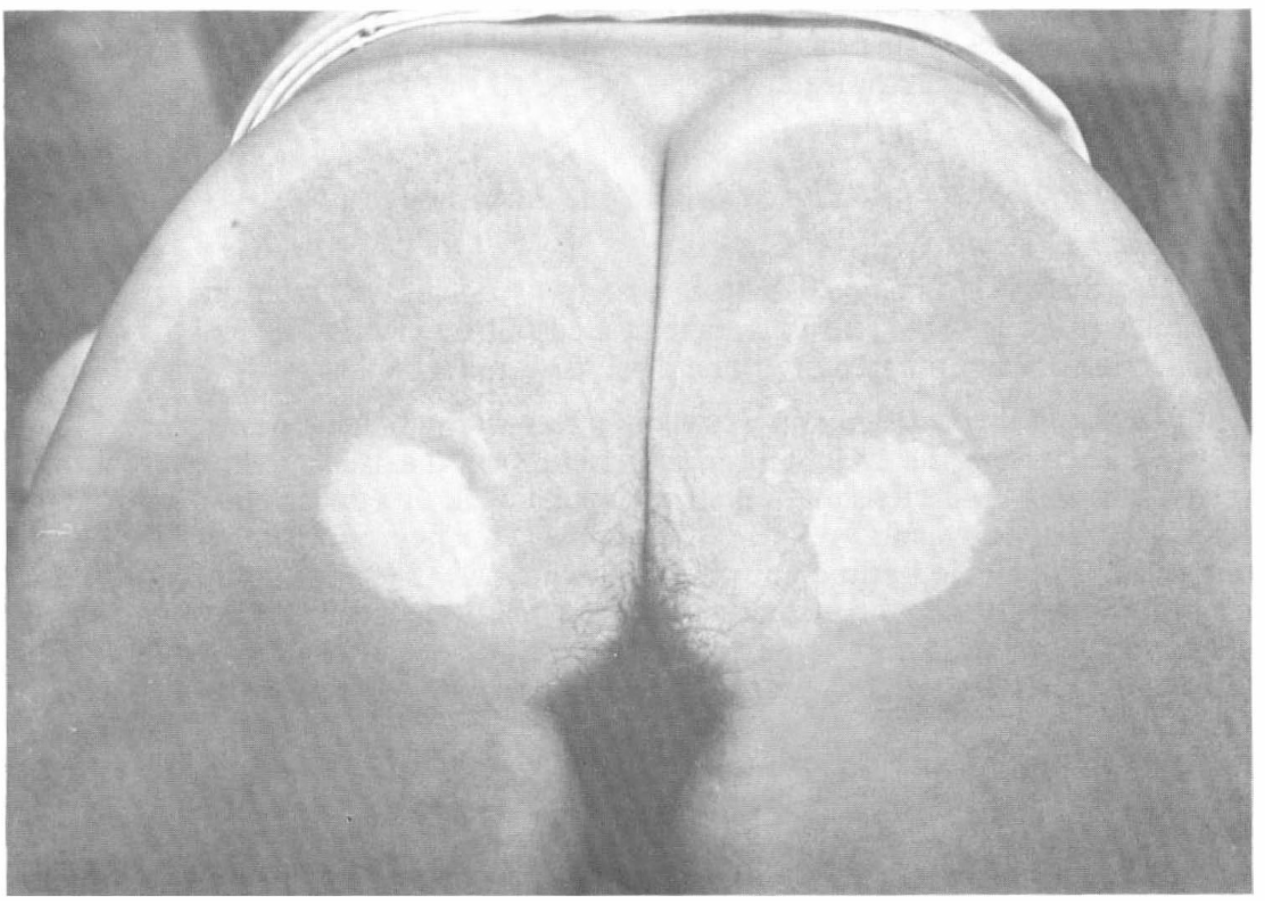

FIG. I

Human rump seated on glass, ischaemia confined to area over tuberosities. 
pressure of $700 \mathrm{~mm} \mathrm{Hg}$ in this area, with the subject seated on a board. Pressures elsewhere were only a fraction of this. This suggests that the skeleton transmits body weight directly to a natural hard surface, and that the surrounding soft tissues are only incidental in supporting body weight. If an emaciated subject is seated on glass, it can be seen that this is so. Should necrosis occur, it will be confined to a small area of relatively unimportant tissue. Voluntary muscle, the sciatic nerve, urethra, anus and genitalia are all protected from ischaemia and pressure. This can be verified, because symptoms of pressure on the sciatic nerve do not arise with indefinite sitting. It is also possible to urinate (see Fig. 2).

Seated on a flat surface, there is great laxity of skin which allows small objects such as pebbles to be accomodated with comfort, unless they locate directly under a tuberosity. The distance $\mathrm{A}, \mathrm{B}, \mathrm{C}$ is greater than the projected distance $\mathrm{A}, \mathrm{C}$. (see Fig. 2).

Under natural conditions the ground absorbs heat from the tissues. The frequency of postural change for relief of pressure depends on the ischaemic survival time of skin and fascia at a reduced temperature. From Haimovici (I976) a period of immobility for hours should be tolerated. The fatty tissue of an obese individual acts like a soft cushion: this is explained later.

Seated on a hard flat surface, pressure can be relieved over the tuberosities by simply leaning forward, equivalent to $120^{\circ}$ of hip flexion (see Fig. 3). This is possible because the soft lax tissues allow the ischia to glide back and forth with remarkable ease. Secondly, the radius from the centre of the acetabulum to the tuberosities is greater than that to the ramus and pubis. This may provide a cam lock effect in maintaining the erect sitting posture. It would appear therefore, that if a patient were seated on a flat board, relief of pressure over the ischia, with the prevention of decubiti should be possible by simply leaning forward and back every few minutes. In practice, this would fail due to depression, lapse of self care, intoxication, quadriplegia, etc.

\section{Wheelchair Cushion}

\section{Conventional Seat Appliances}

The thick wheelchair cushion is widely used, without scientific proof of its efficiency (see Fig. 4). The advantage of a cushion is that it protects the buttocks transferring on and off a chair. The disadvantages are:

(A) Psychological: patient erroneously feels safe: discourages lifting.

(B) It defeats the weight-bearing function of the ischia. Pressure is converted into soft tissue tension and sheer force which is a most efficient producer of ischaemia (Guttmann, I955). Therefore frequency of lifting is dictated by the warm muscle ischaemic injury time, which is the Minimum Physiological Mobility Requirement for man supported on a soft surface, i.e. the patient must lift himself every I I. 6 minutes. Injured muscle may repair itself, it is possible that the majority of ischaemic lesions or sores not being visible go undetected by the uninformed.

(C) The protective function of the ischia is nullified. Urinary obstruction even with a catether in situ may result, with the risk of urinary flare-up and other complications in the male (see Fig. 4).

(D) A cushion reduces the natural high pressure over the ischia which is the natural stimulus necessary to produce thickened protective skin.

(E) The patient has to lift his body weight completely off the cushion to 
ensure tissue blood flow. The shoulder joint is not a weight-bearing joint. Years of this abnormal stress may produce pathology in the joint.

(F) In practice the wheelchair cushion does not prevent decubiti. It, like all pressure distributing appliances, implicates the ischial bursa in sitting, and produces the common ischial bursitis.

\section{The Alternating Pressure Seat}

This seat functions on the principle intended by the ripple mattress, i.e. the alternating change of support points under the buttocks (See Fig. 5-'Theoretical function of the alternating pressure seat'). Pressure on points $I, 3,5$ is transferred every few minutes to position 2, 4, etc. This would in fact be true

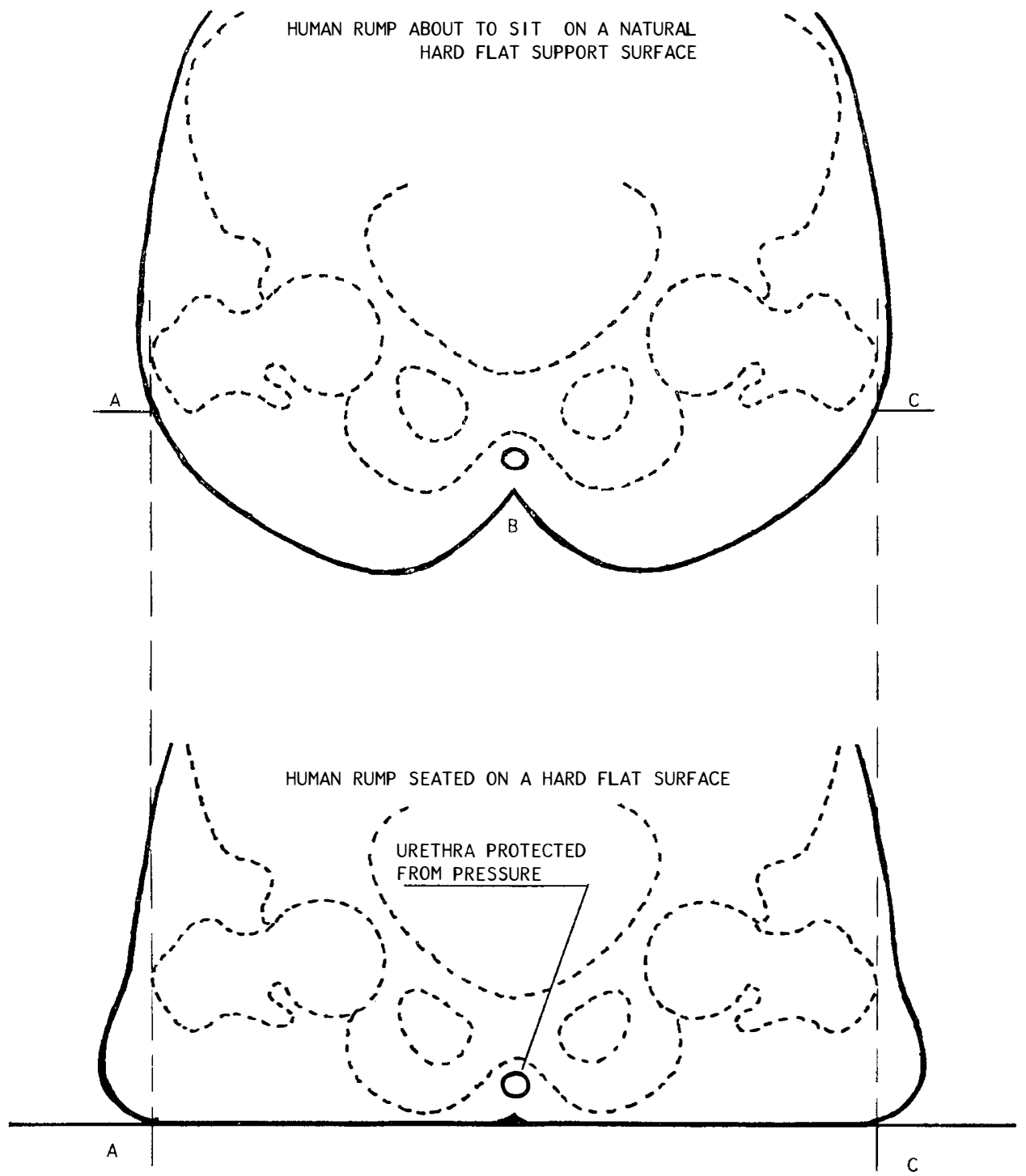

FIG. 2 


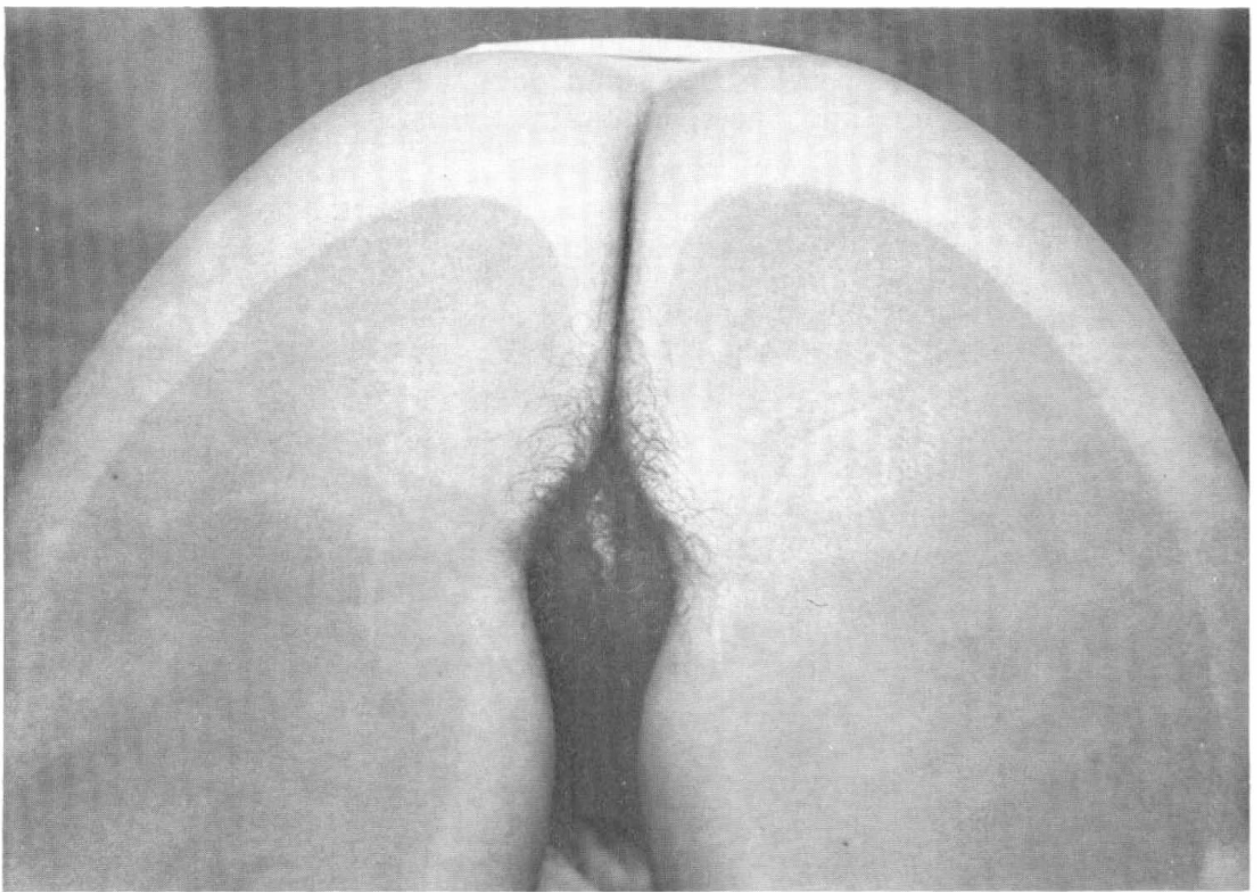

FIG. 3

Subject seated on glass, leaning forward a distance equivalent to $120^{\circ}$ of hip flexion.

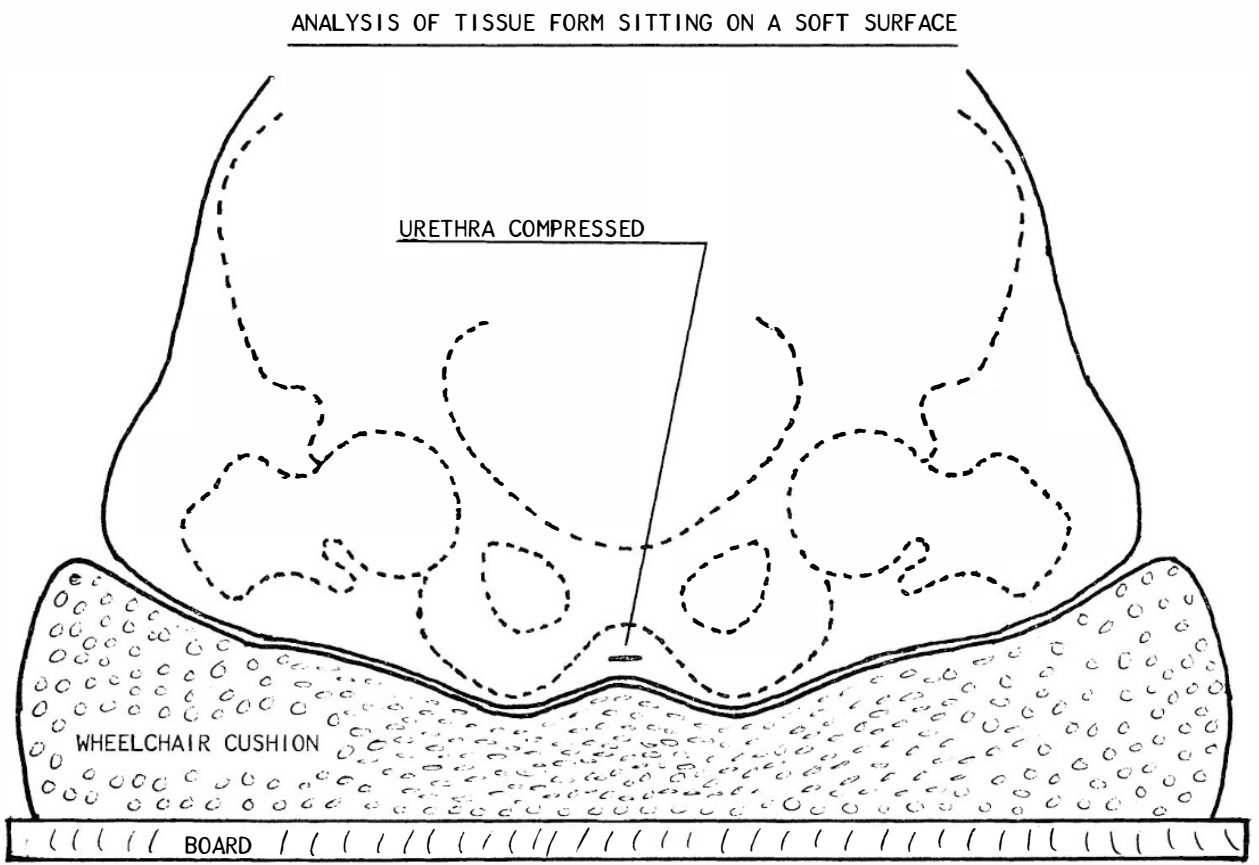

FIG. 4 
if the body were a rigid hard homogeneous object. The human body is a complex mass, with a rigid weight-bearing skeleton, covered by compressible distortable tissues. The actual effect produced, sitting on this seat is illustrated by Fig. 5'Function of the alternating pressure seat in vivo'. Skin over raised cells is compressed, pressure is relieved over the deflated cells, but, the soft tissues have to support body weight acting through the ischia. The skin therefore forms a sling between the inflated cells, thus pressure is converted into high tension, which causes ischaemia between the inflated cells. The skin of the buttocks is therefore under continuous tension, and the deep tissue under continuous compression with changing tension. Consequently, ripple seats, alternating small cell pressure mattresses cause continuous skin and tissue ischaemia.

\section{The Floatation Pad or Liquid Filled Cushion}

Figure 6 shows a subject seated on one of these seat devices. The weightbearing function of the ischia is nullified. Pressure is effectively equalised all over the skin, only when soft tissue distortion is fully established. The pressure

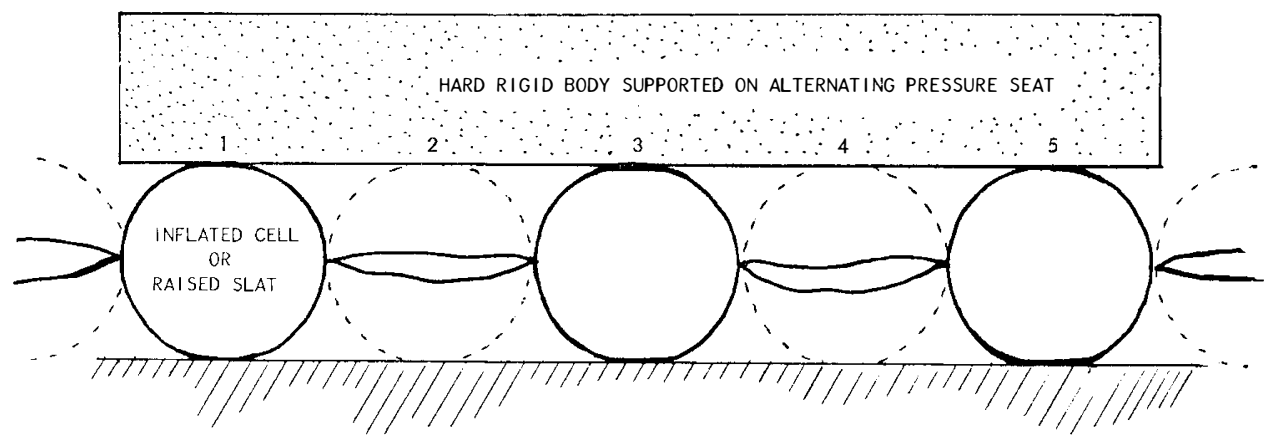

THEORETICAL FUNCTION OF THE ALTERNATING PRESSURE SEAT

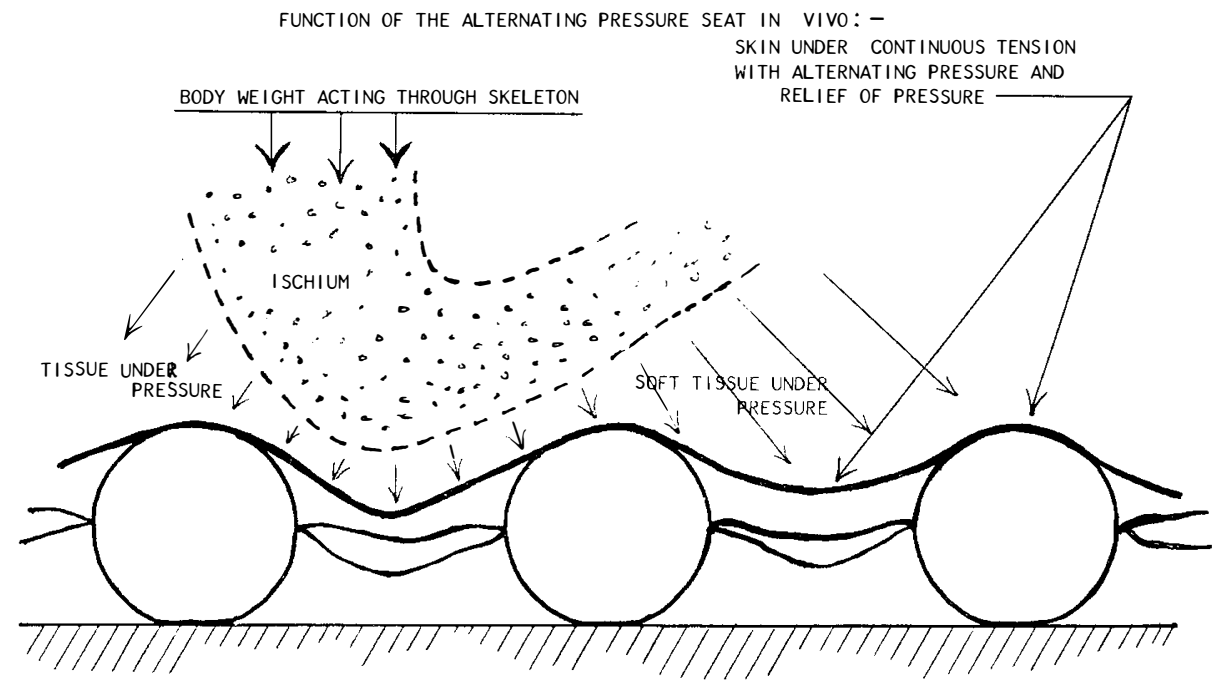

FIG. 5

I6/4 E 
being transferred from the complex bony structure to the soft tissues is obviously not equalised. Complex stresses develop in the deep tissues, with production of ischaemia. Invisible deep-seated muscle and tissue necrosis does arise but may pass undetected. Such a device is dangerous.

\section{Holes in the Wheelchair Seat}

Kosiak (I96I) rightly pointed out that the practice of using a board with a cut-out under the wheelchair cushion to relieve pressure over the ischia simply transfers body weight elsewhere. This may tend to shift the location of sores but obviously cannot prevent them.

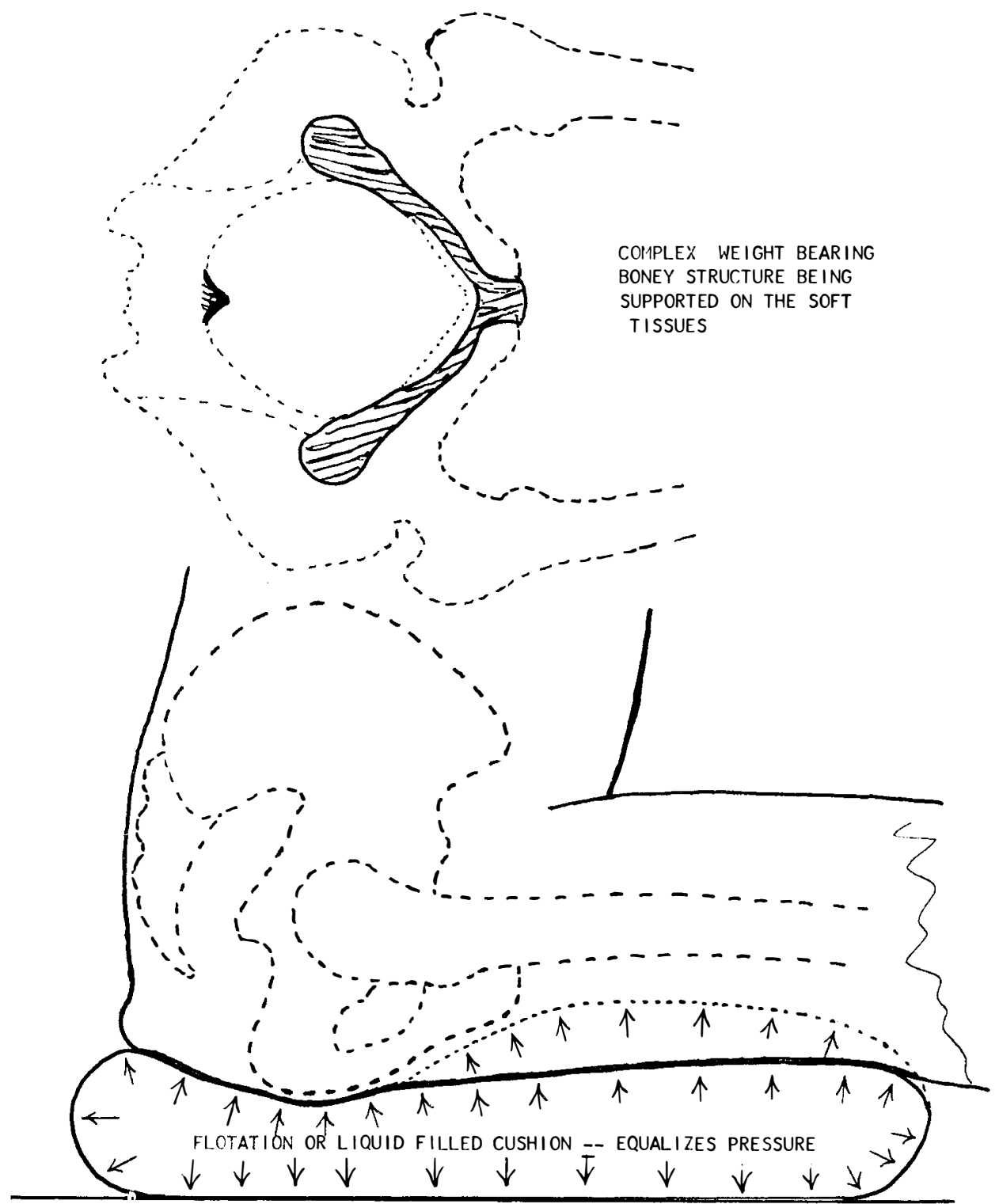

FIG. 6 
The Keane Reciprocating Wheelchair Seat

From what has been discussed, and the complex problem of supporting a body weight bearing skeleton, embedded in vital distortable tissue, I believe there is no safe method of preventing decubiti and other complications, other than the natural or physiological, i.e. restoration of patient mobility and the proper use of the weight-bearing bony prominences.

The patient must be mobliised by mechanical means. With present technology, pneumatics or hydraulics are unreliable. Unfailing maintenance-free life-time service is required. A machine can be designed to do this.

A toilet seat, while unphysiological is an acceptable support for periods

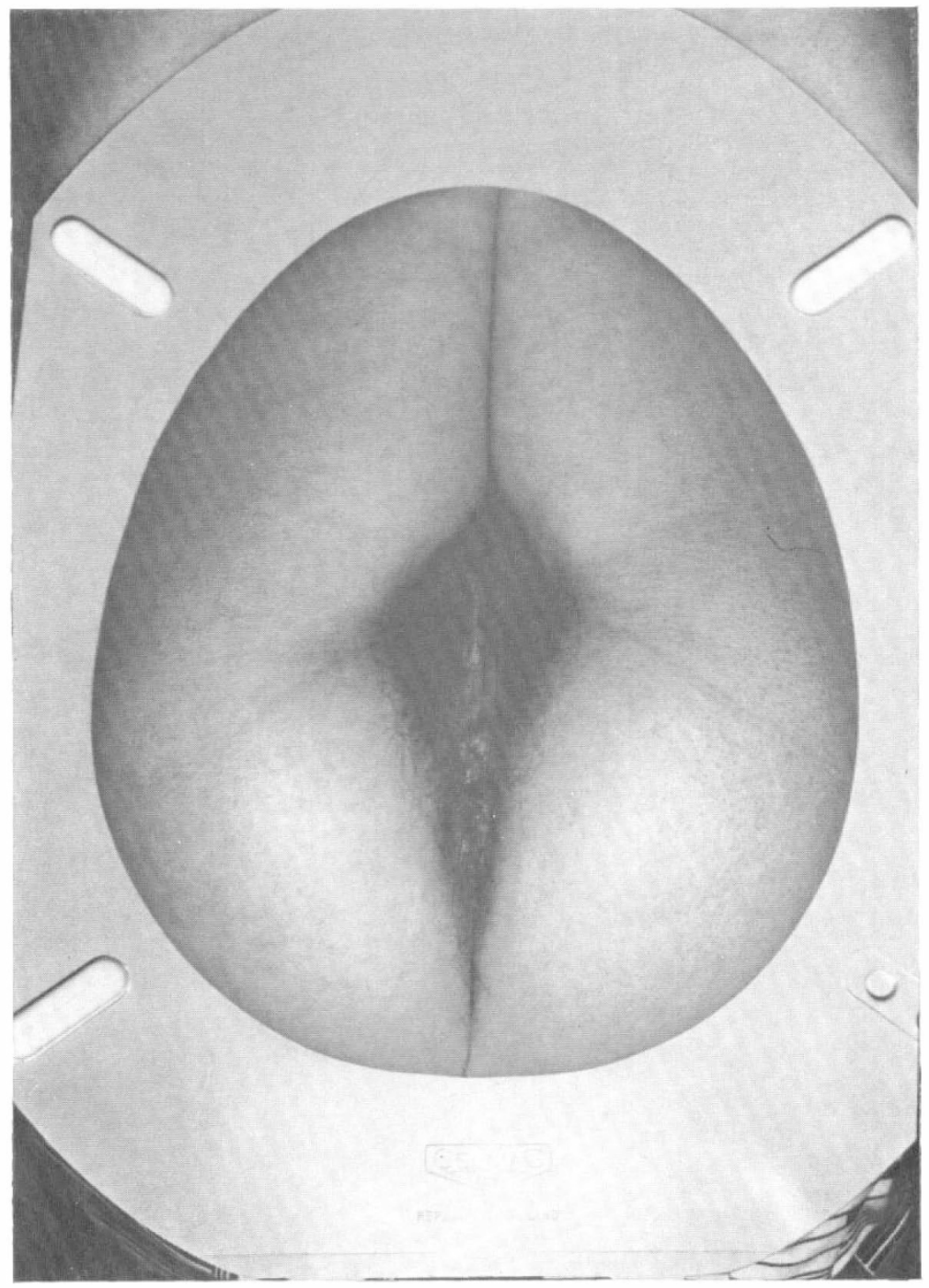

FIG. 7

Subject seated on toilet seat. Note: no area of skin ischaemia. 
measured in minutes. We all know this from experience. Parasthesia and numbness arise after $12 \mathrm{~min}$, due to pressure on the sciatic nerve; there being no weightbearing bony prominences to prevent this. Figure 7 shows a subject supported on a toilet seat. It can be seen when compared with Fig. I that normal blood

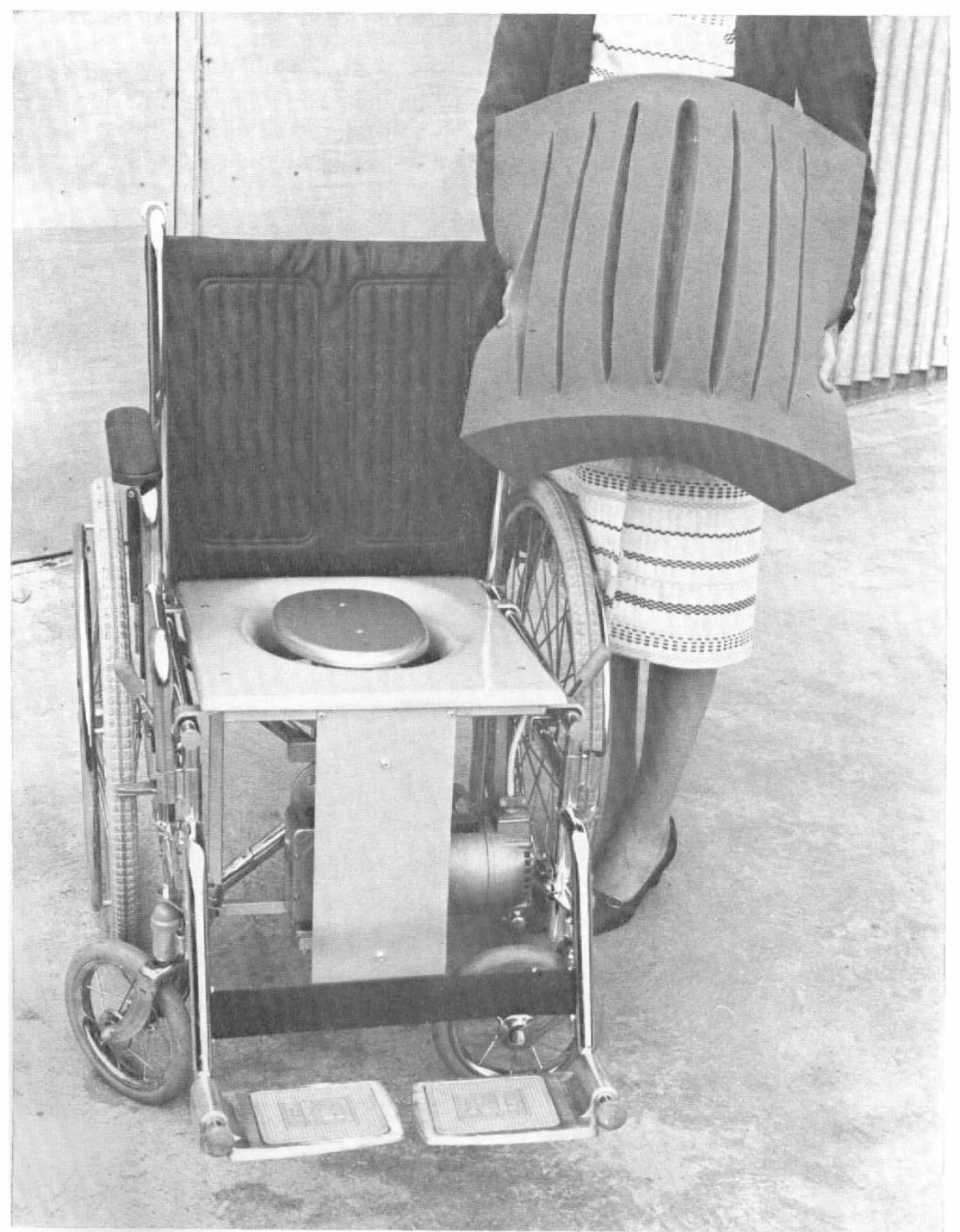

FIG. 8

Keane Reciprocating Wheelchair Seat-central seat in up position. Note: foam cushion with longitudinal cuts in under surface. 
circulation in the skin is possible. When felt, the tissues are soft and relaxed. The area of the buttocks enclosed by the seat is so large that there is obviously no interruption of blood supply entering the deep tissues (See Fig. 9). Body. weight is taken on the muscles compressed against the posterior aspect of the proximal end of femur.

The Reciprocating Wheelchair Seat consists of a substantially elongated toilet seat, with a central elliptical flat seat (see Fig. 8). The central seat is mounted for vertical reciprocation on linear bearings. The seat is lifted and lowered on a simple circular cam, mounted on a brushless, electric motorised gear reduction unit. A complete cycle takes $9 \mathrm{~min}$ ( $4 \frac{1}{2} \mathrm{~min}$ to rise and $4 \frac{1}{2} \mathrm{~min}$ to fall). This is well within the Minimum Physiological Mobility Requirement for man supported on a soft surface.

The central seat forms a natural flat surface with which to raise the body. making proper use of the ischia. The central seat rises far enough to lift the subject off the surrounding toilet seat, and guarantees blood flow restoration along the posterior aspects of the femora. In effect therefore the patient is mobilised: being lifted and lowered a distance of $5 \mathrm{~cm}$. Since this is a slow operation, the patient is unaware that he is being lifted: there is no interference with his work. In the down position, the reciprocating seat has to fall $13 \mathrm{~cm}$ to ensure that the buttocks penetrating the surrounding seat comes completely free of the reciprocating seat (see Fig. 9).

In a wheelchair, the seat is mounted at an inclination, so that the patient is lifted upwards and backwards into his chair. The surrounding seat is contoured to produce re-centring of the patient in his chair, every time the reciprocating seat lowers him onto the surrounding seat.

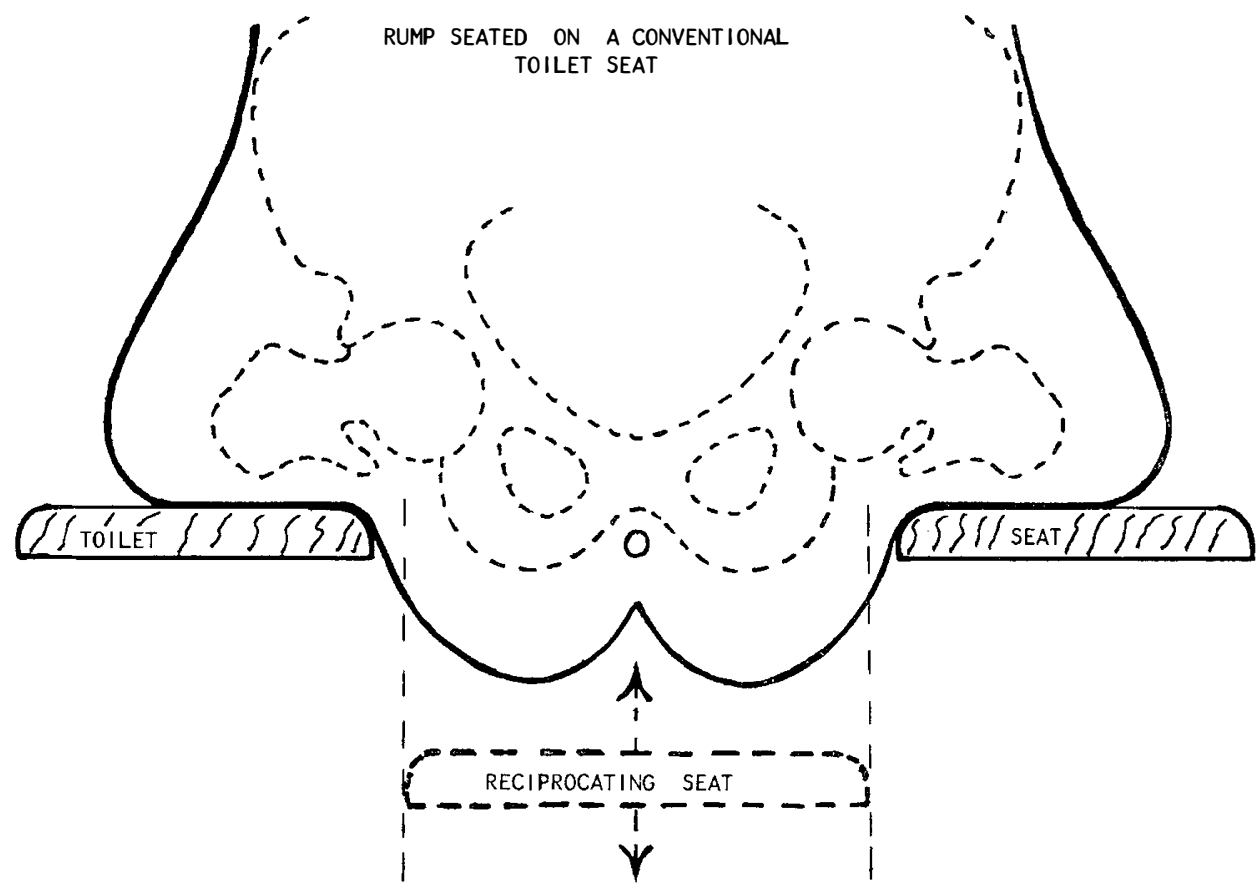

FIG. 9 
In practice, and without ill effect, it is possible to use a cushion on the reciprocating seat. The cushion must be of relatively open cell foam plastic to allow ventilation of the buttocks. It must have no fabric cover which has a bridging effect and prevents complete relief of pressure. The cushion must have deep longitutinal slits in the under surface (see Fig. 8) to allow it follow the reciprocating seat down, also avoiding a bridging effect. The cushion has advantages that: it prevents lax skin on the geriatric buttocks from being pinched between the seats; it prevents faeces and urine from reaching the mechanism; and it removes the hard appearance of the seat and prevents buttock contusion during transfer on and off the seat.

\section{Treatment of Ischial Sores}

I have used this seat successfully since I970, in the treatment of ischial sores. It at first appears unlikely that granulation tissue covering bone can be repeatedly subjected to very high pressures. However, on reflection the tissues of terrestrial animals are capable of healing under these natural conditions. Cicatrisation continues once the Minimum Physiological Mobility Requirement is satisfied. That sores can heal with the patient sitting on them, means that bed rest is no longer necessary, and the patients' occupation is not interrupted. The use of Kinetic Nursing in bed avoids the necessity for the prone position.

\section{SUMMARY}

The problem of decubiti from immobile sitting still remains. Many patients have to sit on chronic sores. Because of visible skin ulceration in the area of the ischia, and the emphasis laid on pressure as the cause of decubiti, all seat devices to date, are designed to: totally relieve, intermittently relieve, or reduce the pressure on the skin in the area of the ischia. Their efficiency is assessed by actual skin pressure measurements.

Body weight acts through the skeletal of all terrestial animals. The skeleton is supported on a natural hard suface, by superficial weight-bearing bony prominences, such as the ischia, which are only covered by skin and superficial fascia. The ischia also protect vital structures: urethra, anus, genitalia, muscle, sciatic nerve and arteries, when man sits on a hard surface. Conventional seat devices transfer weight-carrying function from the ischia to the soft tissues: function is reversed. The skeleton transmitting body weight is then supported by vital tissue. Muscle damage and necrosis arises in advance of skin necrosis. Therefore, while not intentional, conventional appliances can produce massive deep tissue necrosis which will arise from a shorter period of immobile sitting. In addition, the protective role of the ischia is lost. Urethral obstruction with urinary flare-up and other complications are possible. These unphysiological seat devices continue to be used, because they are thought to function, when in reality the patient who remains free of decubiti does so in spite of these devices, because the patient is mobilised by lifting.

It would appear from rump function, that the natural or physiological means of preventing decubiti, and other complications, is the only safe method. It is ischaemia caused by immobility, and not pressure which is of a normal degree, that is responsible for pathology.

The Keane Reciprocating Wheelchair Seat functions by mobilising the patient, well within the Minimum Physiological Mobility Requirement for man, supported on a soft surface, i.e. a lift every i 16 minutes. The seat consists of an 
outer toilet shaped seat, and an inner flat seat, which is raised and lowered by mechanical means and an electric motor. The patient is lifted on his ischia, a height of $5 \mathrm{~cm}$, and lowered again onto the surrounding seat. This takes $4 \frac{1}{2} \mathrm{~min}$. The patient is unaware that he is being lifted because the process is slow. The central seat falls $13 \mathrm{~cm}$ below the surface of the surrounding seat, so that contact with the ischial area is broken. This seat allows the use of a cushion without it's unphysiological undesirable effects.

We have used these seats since 1970 for the treatment of ischial sores. This proves that granulation tissue can withstand normal pressures, i.e. pressure exerted by body weight against a natural surface. This is an important fact because it means that a patient can avoid bed rest and remain at work. Pressure therefore, does not have to be totally relieved for sores to heal.

\section{RÉSUMÉ}

Le problème des eschares provenant de la position assise immobile reste posé. De nombreaux patients sont obligés de s'asseoir sur des eschares chroniques. A cause de l'ulcération visible de la peau dans la région ischiatique et du fait que les eschares sont souvent causés par la pression de la position assise, tous les appareils de siège sont actuellement concus pour: apporter un soulagement total, apporter un soulagement intermittent, reduire la pression sur la peau dans la region ischiatique. L'efficacité de ces sièges est déterminée par des mesures prises sur la pression sur la peau.

Le poidsdu corps agit à travers le squelette des tous les animaux terrestres. Le squelette est soutenu sur une surface naturelle dure par un poids superficiel avec protubérances osseuses, telles que l'ischia, recouvertes seulement de peau et d'une aponevrose superficielle. L'ischia protège également les structures vitales: l'urètre, l'anus, l'appareil génital, le muscle, le nerf sciatique et les arterès quand i'homme s'assied sur une surface dure. Les appareils de siège conventionnels transmettent la fonction est inversee. Le squelette transmettant le poids du corps est alors soutenu par des tissus vitaux. Le dommage au muscle et la nevrose se produisant avant la necrose de la peau. Les appareils conventionnels peuvant donc malencontreusement causer une necrose massive des tissus en profonder et ceci va se produire après une periode relativement courte de position assise. De plus, la rôle proctecteur de l'ischia est perdue. Une obstruction de l'urètre et une inflammation urinaire ainsi que d'autres complications sont egalement possibles. Les appareils de siège non physiologiques continuent à être utilisés et sont senses fonctionner quoique le patient ne souffrant pas d'eschares n'en souffre pas pur la seule raison qu'il est bougé par soulevage. D'après la fonction de la croupe, il semble que le moyen physiologique ou naturel pour la prevention du décubitus et d'autres complications est la seule methode sure. L'ischiemié causée par l'immobilite et non par la pression est normale et ceci est pathologique.

Le siège de chaise roulante de Keane, à mouvement alternatif, fonctionne en bougeant le patient dans les limited du minimum physiologique de mobilité exigé pour l'homme soutenu sur une surface douce, c'est à dire une levée toutes les I I.6 minutes. Le siège consiste en un siège exterieur en forme de siège de toilette, et un siège interieur plat qui sera levé et abaissé mecaniquement ou au moyen d'un moteur électrique. Le patient est soulevé sur son ischium, d'une hauteur de cinq centimetres et abaisse de nouveau sur le siège extérieur. Ceci prend 4. minutes et demie. Le patient ne se rend pas compte qu'il est souleve car le procede est tres lent. Le siège central retombe treize centimetres au dessous de la surface isciatique. Ce siège permet l'utilisation d'un coussin et evite les effets non physiologiques que cella peut entrainer.

Nous utilisons ces sièges depuis 1970 pour le traitment des eschares. Ceci prouve que le tissus de granulation peut supporter une pression normale c'est à dire la pression exarcée par le poids du corps contre une surface naturelle. Ceci est un avantage important puisque cela signifie que le patient n'est pas obligé de rester au lit peut continuer son travail. La pression n'a donc pas besoin d'être éliminée completèment pour que les eschares se cicatrisent.

\section{ZUSAMMENFASSUNG}

Das Problem der Verletzung durch unbeweglisches Sitzen bestebt immernoch: Viele Patienten müssen auf chronischen wunden sitzen. Wegen sichtbarer Eiterung der 
Gesässbeinzone und wegen Betonung auf Druck als Ursache dieses Druckbrandes sind alle bisherige Sitzgeräte dazu bestimmt worden, dass sie den Hautdruck in der Gesässbeinzone vollig erleichtern, oder abschwächen sollen. Mon schätzt ihren Nutzeffekt auf aktuelle Hautdruckmessungen.

Das Körpergewicht funktioniert bei allen irdischen Tieren durch das Skelett. Das Skelett ist auf einer harten Naturfläche von oberflächichen gewichttragenden knöchernen Protuberanzen wie des Gesässbeins unterstützt, die nur mit Haut und oberflächlichen Faszien eingehüllt sind. Das Gesässbein schüzt auch Lebensorganismen: Harnröhre, After, Genitalien, Ischiasnerven und Pulsadern, wenn der Mensch sich auf eine harte Oberfläche sezt. Die üblichen Sitzgeräte versetzen die Gewichttragen Fähigkeit des Sitzbeins auf den weichen Gewebe: diese Fähigkeit wird umgekehrt. Das Skelett, das das Körpergewicht überträgt, ist dann von Lebensgweben unterstützt. Beschädigung und Nekrose an Muskeln geschehen vor Haütnekrose. Daher können die üblichen Geräte schwere tiefe Gewebsnekrose erzeugen, die aus einer kurzeren Periode unbeweglichen Sitzens entsteht. Ausserdem spielt das Gesässbein dabei keine schützende Rolle. Verstopfen der Harnrohre mit Urinretention und andere, Komplicationen sind möglich. Unphysiologischen Sitzgeräte sind immernoch in Gebrauch, weil man denkt, dass sie. In der Tat bleibt der Patient sitzbrandfrei trotz dieser Geräte, weil der Patient mobilisiert wird, dadurch dass er emporgehoben wird.

Der Gesässbeinfunktion nach scheint es, dass das physiologische Mittel zur Verhutung von Sizbrand und anderen Komplicationen das einzige Mittel ist. Die Blutarmut durch Unbeweglichkeit und nicht der Druck in gewöhnlichem Masse ist fur die Pathologie verantwortlich.

Der Keane wechselwirkende Rollstuhlsitz funktioniert, indem er den Patienten mobilisiert, und zwar innerhalb des minimum physiologischen Bewegungsbedarfs des Menschen auf einer weichen Oberfläche unterstützt, d.h. je I I.6 Minuten emporheben. Der Sitz besteht aus einem aüsseren toilettegestalteten Sitz und einem inneren flachen Sitz, der mechanisch von einem elektrischen Motor auf und abgezogen wird. Der Patient wird bis fünf Zentimeter hoch auf das Gesässbein emporgehoben und dann wieder zum

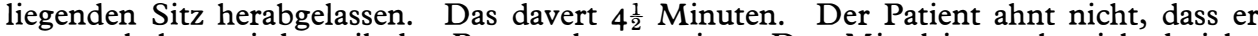
emporgehoben wird, weil der Prozess largsam ist. Der Mittelsitz senkt sich dreizhn Zenimeter unter die Fläche desumliegenden Sitzes, sodass Kontakt mit der Gesässbeinzone unterbrochen wird. Bei Anwendung dieses Sitzes kann man ohne unerwünschte Effekete ein Kissen benutzen.

Diese Sitze haben wir seit 1970 in der Behandlung der Sitzbrandwunden benutzt. Das bestätigt, dass das Granulationsgewebe einem normale Druck Widerstand leisten kann, d.h. dem Druck, den das Körpergewicht gegen eine natürliche Fläche ausübt. Dies gilt als wichtiger Vorteil, denn es bedeutret, dass ein Patient Bettruhe vermeiden und bei der Arbeit tätig bleiben Kann. Es ist daher nicht nötig, den Druck völlig wegzuschaffen, damit die Wunden heilen können.

\section{REFERENCES}

Gray's Anatomy (1969). The Skin, 2nd imp., 34th edit., p. I343. Longmans, Green \& Co. Ltd., London.

Groath, K. E. (1942). Acta Chir. Scandinav., Suppl. 76: I.

GutTMANN, L. (I953). Injuries of the spinal cord. Surgery, Sir Zachary Cape, 422-5I6.

GutTMANN, L. (I955). The problem of treatment of pressure sores in spinal paraplegics. Brit. F. of Plastic Surg., 8, 196-213.

Haimovici, H. (1976). Vascular Surgery, p. 285. McGraw Hill Book Co., New York.

Houle, R. J. (1969). Evaluation of seat devices designed to prevent ischaemia. Amer. F. Path., 23, 55I.

Husain, T. (I953). An experimental study of pressure effects on tissues with reference to the bedsore problem. F. Path. E Bact., 66, 347-358.

Kosiak, M. (1959). Etiology and pathology of ischaemic ulcers. Arch. Phys. Med., 40, $62-69$.

Kosiak, M. (196I). Etiology of decubitus ulcers. Arch. Phys. Med. E Rehab., 19-28. 